DOI: 10.25178/nit.2018.3.15

\section{ВЕДОМОСТЬ ТОПОНИМИКИ МЕЖДУРЕЧЬЯ АЛАШ-ХЕМЧИК}

\section{PLACE NAMES OF THE ALASH-} KHEMCHIK INTERFLUVE: A LIST

\author{
Лина К. Хертек \\ Независимый автор, \\ Российская Федерация
}

\author{
Lina K. Khertek \\ Independent researcher, \\ Russian Federation,
}

В статье представлено исследование топонимикимеждуречья Алаш-Хемчикв Бай-Тайгинском кожууне Тувы: сбор, систематизация, этимологизация, определение мотивировки географических топонимов и составление ведомости. Были использованы материалы Тувинской геологоразведочной экспедиции 1962-1964 г2., топографические карты территории, приведены сведения информантов из числа местных жителей БайТайгинского кожууна, опрошенных автором в 2000-2001 г2., а также материалы научных публикаций.

Топонимические исследодвания Тувы проводились разными авторами. Однако углубленного изучения топонимики отдельных районов, в том числе Бай-Тайгинского кожууна и междуречья Алаш-Хемчика не производилось. Топонимия исследуемого района отличается богатством и разнообразием. Автором выделены группы топонимов: отражающие цвет, определяющие местоположение, связанные с названиями растений, определяющие форму элементов ланшафта, связанные с количеством, выражающие размер, связанные с каким-либо происшествием, событием; относящиеся к священным названиям, определяющие вкус воды, определяющие высоту гор, связанные с этнонимами. Большинство географических названий связаны с определенными геологическими породами или структурами. Например, Сарыг-Хая - “желтая скала”, Кара-Даш “черный камень”, Ак-Довурак - “белая земля” и др.

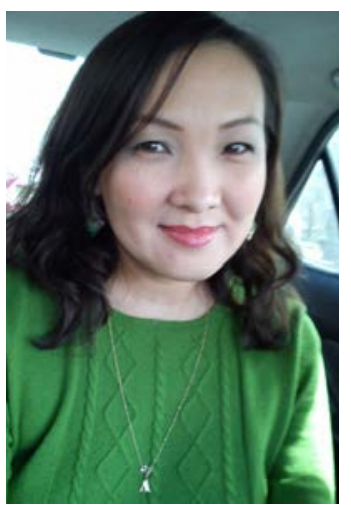

This article examines the toponymy of the Alash-Khemchik interfluve in Bai-Taiga kozhuun of Tuva. Our study included gathering the materials, classification, etymological research, determining the motivation of geographical place names and, finally, compilation of the list. The study of the toponymical materials is based on the data of Tuvan geological exploration 1962-1964, topographic maps of the area, some data gained from the informants interviewed in 2000-2001, and finally, on the information found in scholarly publications.

There have been a number of toponymical studies of Tuva done by different authors. However, some regions, including Bai-Taiga and the AlashKhemchik interfluve, have so far been definitely understudied. The toponymy of this region is unique and rich, with its own variations. The author divided these toponyms into several groups: terms related to colours, places, plant names, land relief, numerals; those reflecting size of an object, or a specific event; those connected with sacred names, explaining the taste of water, the height of mountains; and related to ethnonyms. The majority of the toponyms refer to special geological formation or structures - for

Хертек Лина Кара-ооловна - независимый автор; руководитель отдела продаж почтовых услуг Управления Федеральной почтовой связи Республики Тыва - филиала Федерального государственного унитарного предприятия «Почта России». Адрес: 667000, Россия, г. Кызыл, ул. Дружбы, д. 156а. Тел.: +7 (913) 341-11-11. Эл. адрес: Linatuva@mail.ru

Khertek Lina Kara-oolovna, Independent Researcher; Head of Sales, Tuvan Office, Federal Agency of Postal Service (branch office of Federal State Unitary Enterprise Pochta Rossii. Postal address: 156a, Druzhby St., 667000 Kyzyl, Republic of Tuva, Russian Federation. Tel.: +7 (913) 341-11-11. Email: Linatuva@mail.ru 
Рассмотрены отдельные вышеназванные топонимы междуречья Алаш-Хемчик в трактовке их местными жителями. Собранный материал оформлен в виде ведомости - краткой сводки, списка географических названий исследуемой площади, которая может стать основой для дальнейшего изучения топонимики края. В него включено более 36 названий, известных большинству населения. Ведомость сопровождается указателем принятых сокращений и объяснением топонимических терминов, встречающихся в словаре. Отмечается проблема искажения названий, неточностей в переводе на русский язык, в написании, присутствующая на картах.

Ключевые слова: Тува; топоним; Алаш; АлашХемчик; Бай-Тайгинский кожуун; тувинский язык; ведомость instance, Saryg-Haya ("the yellow mountain"), Kara-Dash ("the black rock"), Ak-Dovurak ("the white earth") etc.

Some of the abovementioned place names have been analyzed here in the interpretations provided by local residents. The gathered material is in the form of list of the geographical names of the area, which is a good starting point for further research. The list includes more than 36 names, known by the most part of the locals. The list is accompanied with an index of accepted abbreviations and explanations of toponymical terms found in the dictionary. There also is a problem of linguistic corruption of place names and inaccuracies in Russian translation in maps. Keywords: Tuva; toponym; Alash, AlashKhemchik, Bai-Taiga kozhuun; Tuvan language; list

\section{Введение}

Географические названия относятся к числу важнейших памятников культуры. Созданные на разных языках, в разное время, они отражают всю многовековую историю человечества: природные условия его существования, материальную и духовную жизнь в их непрерывном развитии. Интерес к названиям, стремление понять их скрытый смысл и связь с именуемым объектом наблюдается со времен Древней Греции и Рима, причем с развитием образования и культуры этот интерес постоянно растет (Поспелов, 1998: 3-5).

Изучение топонимики Тувы как одного из проявлений духовного наследия предков тувинского народа имеет важное значение для культурного развития нашего общества, воспитания у будущих поколений любви и уважения к своему родному краю. В современных условиях, когда идет процесс возрождения национальных культур, в новом качестве происходит осознание народом своего этногенеза.

В статье представлено исследование топонимики междуречья Алаш-Хемчик в Бай-Тайгинском кожууне Тувы (рис. 1), так как на данной местности - Хертек суму (родоплеменное имя, по линии отца) - с давних пор проживали мои предки. С малых лет мне приходилось кочевать из кыштага (зимнее стойбище) в чайлаг (летнее стойбище). Поэтому мне дорог этот край, и я стремлюсь побольше о нем узнать. Эта давно задуманная работа была осуществлена во время учебы на естественно-географическом факультете Тувинского государ- 


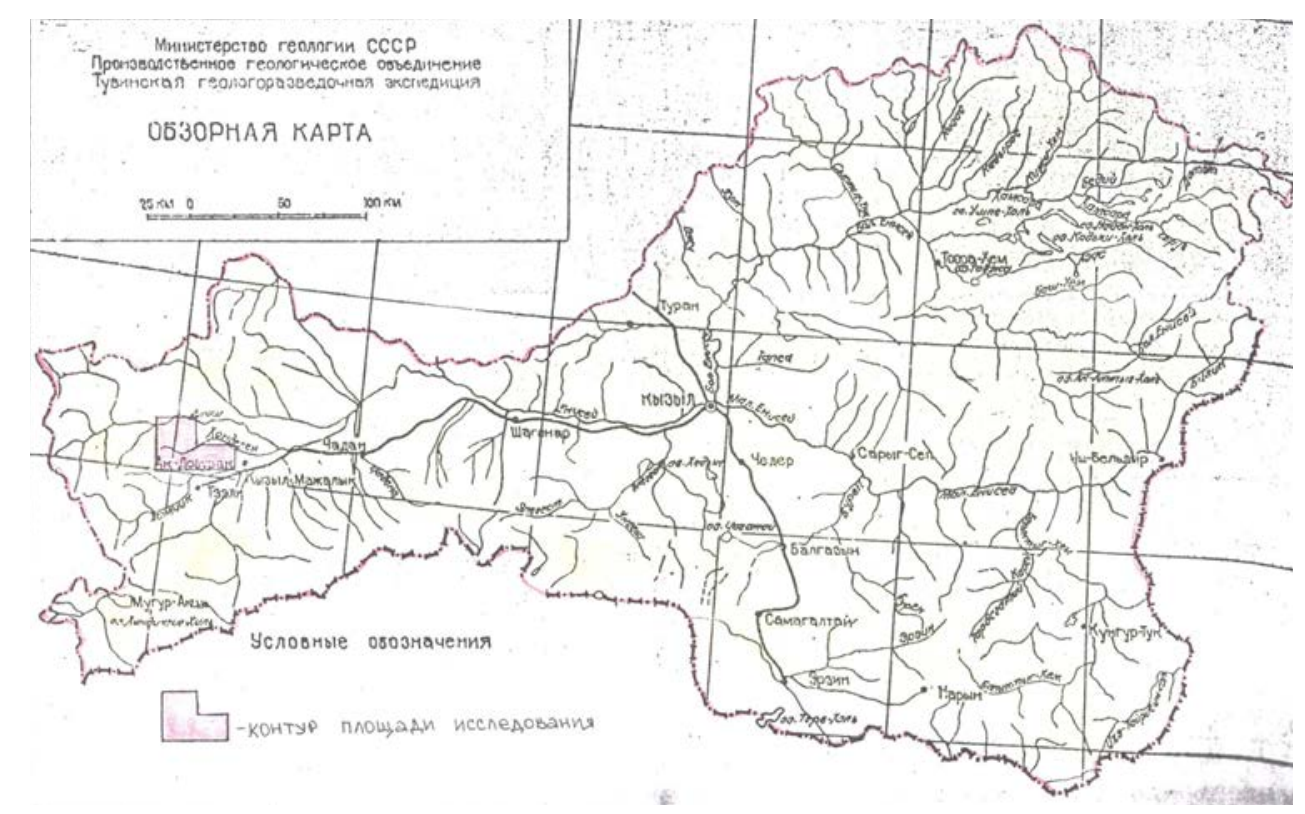

Рис. 1. Обзорная карта расположения площади исследования (Геология СССР, 1966: 8). Fig.1. An overview map of the research area (Geologiya SSSR, 1966: 8).

ственного университета в рамках выпускной квалификационной работы (Хертек, 2001). А данная статья представляет собой ее сокращенный и немного доработанный вариант ${ }^{1}$.

Целью работы являлись сбор, систематизация, этимологизация, определение мотивировки географических топонимов междуречья Алаш-Хемчик в БайТайгинском кожууне Тувы. На реке Алаш находятся населенные пункты как п. Кара- Холь и п. Кызыл-Тайга, на реке Хемчик располагаются следующие населенные пункты: сверху вниз Бай-Тал (Чон-Терек), Тээли, Аксы-Барлык, Барлык.

При написании работы были использованы материалы Тувинской геологоразведочной экспедиции ${ }^{2}$, топографические карты территории Алаш - Хонделен - Хемчик масштабов 1:25000 и 1:100000 геолого-съемочных работ партий Тувинской геолого-разведочной экспедиций, приведены сведения информантов из числа местных жителей Бай-Тайгинского кожууна, которых автор опрашивала в 2000-2001 гг., а также дипломная работа выпускницы филологического факультета Тувинского государственного университета Р. А. Хертек (Хертек, 2000), посвященная топонимам Бай-Тайгинского кожууна.

\footnotetext{
${ }^{1}$ В процессе работы большую методическую помощь и внимание мне оказывал старший геолог Тувинской геологоразведочной экспедиции В. А. Попов. Помогли материалами к. ф. н. М. В. Бавуу-Сюрюн и старший научный сотрудник ТувИКОПР СО РАН В. И. Кудрявцев. Постоянную поддержку и помощь мне оказывал научный руководитель дипломной работы - к. г-м. н. В. И. Забелин. При доработке данной статьи большую помощь оказал ведущий научный сотрудник ТувИКОПР СО РАН, к. г.-м. н. А. А. Монгуш. Всем перечисленным лицам от всего сердца выражаю искреннюю признательность.

${ }^{2}$ Авруцкий, В. Л. Геологическое строение и полезные ископаемые междуречья Алаш-Хемчик / Окончательный отчет Байтайгинской геолого-съемочной партии по работам 1962-1964 гг. Кызыл, Тувинская комплексная геологическая экспедиция. 559 с. Рукопись хранится в архивах Тувинской геологоразведочной экспедиции Тувинского геологического комитета.
} 


\section{История исследования топонимики района}

Топонимические словари Тувы издавались в разные годы разными авторами: «Краткий словарь гидронимов Тувы» и «Топонимический словарь Тувы» Б. К. Ондар (Ондар, 1995, 2007), «Словарь географических терминов и других слов, встречающихся в топонимии Тувинской АССР» М. Б. Волостновой и С. А. Тюрина (Волостнова, Тюрина, 1971), «География терминнеринин орус-тыва допчу словары» под редакцией А. М. Чимба (География ... , 1959).

Помимо этого, топонимические вопросы поднимались в отдельных публикациях филологов. Это работы Ш. Г. Сат (Сат, 1970), Б. И. Татаринцева (Татаринцев, 1993: 105-111), Х. Л. Ханмагомедова (Ханмагомедов, 1987), Б. К. Ондар (Ондар, 1992) и многих других. Интересны и этнографические материалы Д. С. Куулара (Куулар, 1996), А. Д. Арапчора (Арапчор, 1995), С. Иргита (Иргит, 1992), которые не только объясняют правильное написание географических объектов, но и формируют чувство любви, ответственность, бережное отношение к родному краю. Однако, углубленного изучения топонимики отдельных районов, в том числе Бай-Тайгинского кожууна и интересующей нас местности - междуречья АлашХемчика - не производилось. По топонимам всего Бай-Тайгинского кожууна исследование проводила студент-филолог Р. А. Хертек, которая также упоминала характеристику топонимов рассматриваемой местности (Хертек, 2000).

При этом, надо сказать, топонимия исследуемого района отличается богатством и разнообразием. Тувинцы, прекрасные знатоки природы, давали своим рекам, горам красивые звучные названия. Большое количество топонимов района содержит восхваляющие эпитеты, что можно объяснить, с одной стороны, культом гор, водных объектов, а с другой - естественным желанием видеть прекрасное в окружающем мире, любовью к родному краю, его просторам и богатствам. Интересны названия, отражающие быт и хозяйство населения: кочевой образ жизни, скотоводство, охоту, земледелие, древнейшее занятие тувинцев - собирательство. Встречаются также названия животных, растений в географических объектах. Характерны для топонимии района названия, связанные с бытом и духовной культурой народа. Они отражают религиозные представления населения. Также есть названия, которые говорят о народах, населявших территорию Бай-Тайгинского кожууна (Ондар, 1995: 34-36).

Но следует отметить, что большинство местных жителей не знает, как на самом деле появились географические названия на местности, где они проживают.

\section{Классификация географических названий}

Итак, в районе междуречья Алаш-Хемчик можно выделить следующие географические группы топонимов: 


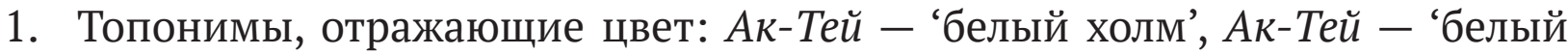
холм', Ак-Довурак - 'белая земля’, Сарыг-Хая - 'желтая скала', Кызыл-Даг 'красная гора', Кызыл-Тей - 'красный холм', Кызыл-Тайга - 'красное высокогорье', Ногаан Хөл / Ногаан-Холь - 'зелёное озеро', Кара-Даш - 'черный камень';

2. Топонимы, определяющие местоположение: Ортаа-Хаак - 'средняя река с тальником', Тээли-Шөлу / Тээли-Шолу - 'поле Тээли', Аксы-Барлык - 'устье Барлыка', Хонделен - 'река, расположенная поперечно по отношению к основной реке - Хемчику';

3. Топонимы, связанные с названиями растений: Чечектиг-Даг - названа по обилию цветущих растений высокогорных лесов (купальница, горечавка, марьин корень т. д.), Шивилиг-Даг - 'гора с обилием ели', Теректиг-Хем - 'река с прибрежными тополевыми лесами’;

4. Топонимы, определяющие форму элементов ланшафта: Калбак-Хая 'плоская скала', Чинге-Даг - 'острая, тонкая гора', Борбак-Даг - 'круглая, овальная гора';

5. Топонимы, связанные с количеством чего-либо: База-Хаак - 'тоже река с мелким тальником';

6. Топонимы, выражающие размер чего-либо: Хемчик - 'речка' (уменьшительное от хем - 'река');

7. Топонимы, связанные с каким-либо происшествием, событием: КөкСөөк / Koоn-Сек - 'долина синих костей';

8. Топонимы, относящиеся к священным названиям: Калбак-Хая - 'плоская скала', Чинге-Даг - 'острая, тонкая гора', Борбак-Даг - 'круглая, овальная гора';

9. Топонимы, определяющие вкус воды: Ажыг-Кара-Суг - 'целебный минеральный источник с кислой водой', Чыдыг-Кара-Суг - 'целебный минеральный источник с неприятным запохом';

10. Топонимы, определяющие высоту гор: Улуг-Даг - 'Большая, крупная гора' (она заметно выделяется среди других окружающих гор), Узун-Даг - 'длинная, высокая гора', Мажалык - 'маленький каменистый холм';

11. Топонимы, связанные с этнонимами: Алаш - предположительно, название связано с тюркским племенным этнонимом алаш, отмеченным у казахов и ногайцев.

Большинство географических названий связаны с определенными геологическими породами или структурами. Такие названия можно отнести к категории производственных. Изучая смысл производственных названий можно получить представление о наличии в тех или иных местах месторождений и проявлений полезных ископаемых. 
Так, например, если брать Туву в целом, то на ее территории имеются месторождения и проявления соли. О них говорят такие топонимы, как Дус - 'соль' (река, Эрзинский кожуун), Дус-Даг - 'соляная гора' (Овюрский кожуун), ДусХөл / Дус-Холь - 'соляное озеро' (Тандинский, Эрзинский кожууны) и др. Недра Тувы богаты всевозможными строительными материалами, среди них есть глина, галька. Они нашли отражения в таких топонимах как Көк-Сайыр / КокСайыр - 'синяя галька' (река, Бай-Тайгинский кожуун), Тойлуг - 'глинистый' (урочище, с. Баян-Кол, Кызылский кожуун) (Ханмагомедов, 1987: 3-4).

В междуречье Алаш-Хемчик мы находим следующие производственные топонимы:

- Сарыг-Хая - “желтая скала” (название указывает на месторождение агальматолита, светло окрашенные желтые мягкие породы, состоящие из глинистого минерала - диккита);

- Кара-Даш - “черный камень” (месторождение глин, в составе неогеновых отложений повсеместно отмечаются глины аллювиально-пролювиального происхождения темной красно-бурой окраски);

- Ак-Довурак - “белая земля” (месторождение асбеста; Ак-Довуракский массив, в основном, сложен залежами габбро. Это белые, серые до зеленовато-серых массивных пород разнообразной структуры от мелко- до крупнокристаллической и пегматоидной);

- Aк-Тей - “белый холм” (проявление магнезита; макроскопически магнезит - это ослепительно белая, плотная порода с раковистым изломом.

К производственным названиям мы отнесли также используемые в работе геологов терминологические названия, которые произошли от топонимов как данного района, так и Тувы в целом: Хемчикская структурно-фациальная зона (от р. Хемчик); Хемчикско-Куртушибинский глубинный разлом; осадочные, осадочно-вулканогенные свиты: магматические комплексы: акдовуракский (от местности Ак-Довурак), алашский (от р. Алаш); интрузивные массивы: Байтайгинский (от г. Бай-Тайга), Хонделенский (от р. Хөнделен), Копсекский (от урочища Көк-Сөөк).

Большинство топонимов Тувы имеют тюркское языковое происхождение, но широко распространен более древний топонимический пласт - самодийский, также встречаются топонимы угро- и кетоязычного происхождения. Значительное распространение, особенно в южных и юго-восточных районах Тувы, имеют монгольские названия (Потапов, 1969: 199).

В топонимии Тувы отмечается смешение разноязычных по происхождению названий. Например, на её территории гидронимы обозначаются различными по звучанию словами, терминами, имеющими одинаковый смысл. Весьма интересны апеллятивы речных систем. Апеллятивы - это такие нарицательные 


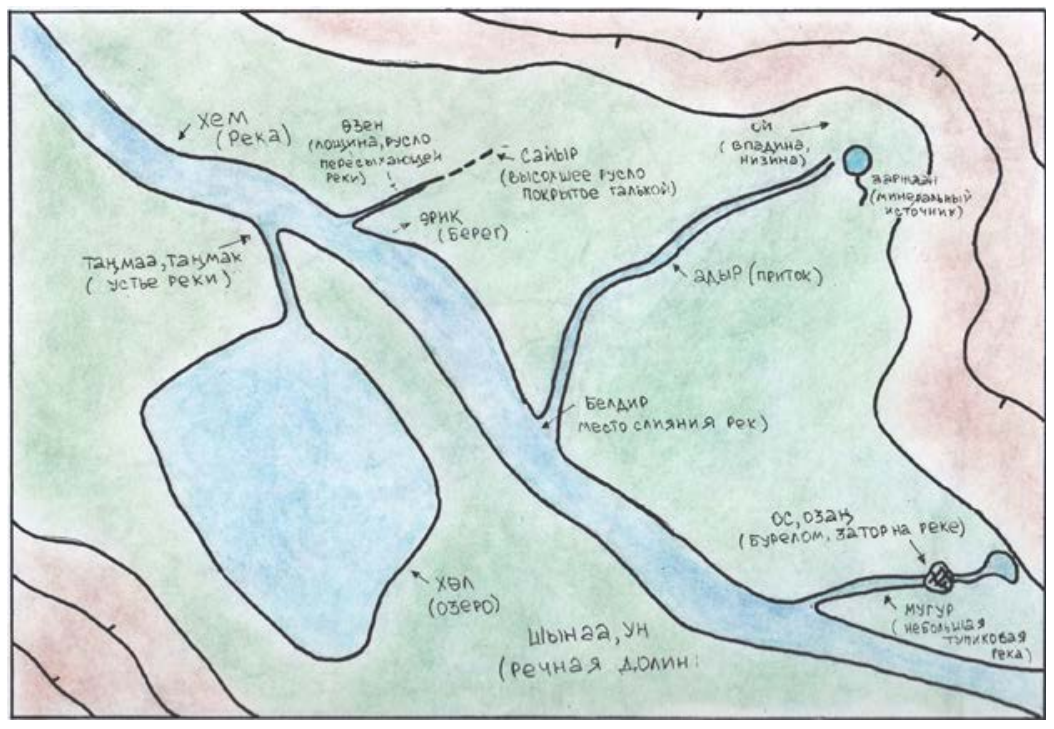

Pис. 2. Аппелятивы речной долины.

Fig. 2. Appellatives of the river valley. имена, как суг - 'вода, река', кол - 'река', адыр - 'приток', мугур - 'небольшая тупиковая река', арт - 'перевал', бажы (баш) - 'вершина, начало, исток', оргу - 'ровный’. Некоторые апеллятивы указывают на характер русла водного объекта и сопутствующие явления в потоке воды: caup - 'высохшее русло реки, покрытое галькой', өзен / озен - 'лощина, русло пересыхающей реки', сай - 'галька, мель', таскыл - 'горный хребет, голец’ и т. д. (Ондар, 1995: 3).

\section{Из истории топонимов междуречья Алаш-Хемчик}

Рассмотрим отдельные вышеназванные топонимы междуречья Алаш-Хемчик в трактовке их местными жителями.

Ак-Довурак. Как пояснила нам Ольга Сергеевна Хертек ${ }^{1}$, название г. АкДовурак привело к открытию месторождения асбеста. Издали гора кажется белой и с давних пор минерал употреблялся как огнеупорный материал. Эту местность называли ак довурактыг даг - 'гора с белой землей'.

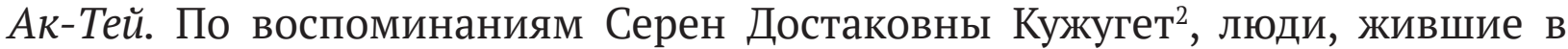
местечке Ак-Тей, отличались гостеприимством, уважительным отношением к природе: по утрам «угощали» хозяина горы молоком, вслед гостям брызгали молоко с пожеланием «белой» (благополучной) дороги - ‘ак орук’

Бай-Тайга. Бай-Тайга - одно из наиболее известных и почитаемых мест Тувы. Местные жители Бай-Тайгинского кожууна с давних пор занимались животноводством и считались богатыми. Также щедра и природа, обильны реки, разнообразен животный и растительный мир (по сообщению Опей Чыргаловича Хертека $\left.{ }^{3}\right)$.

${ }^{1}$ Хертек Ольга Сергеевна, 1955 г. рожд. Моя мама. Филолог, занимается исследованиями о Бай-Тайге. Вдохновила на идею взаимосвязи топонимики и географии.

${ }^{2}$ Кужугет Серен Достаковна, 1910 г. рожд. Сестра моей бабушки. Вела аратское хозяйство около пос. Кызыл-Тайга.

${ }^{3}$ Хертек Опей Чыргалович, 1920 г. рожд. Мой дедушка. Проживал в районе р. Алаш, вел аратское хозяйство. 
Кара-Даш. Кара-Даш часто встречается в тувинских сказках. Связан с нечистой силой (албыс, шулбус), превращенных в камень (сообщение Тавак-оола Самданчаповича Хертека $\left.{ }^{1}\right)$.

Кызыл-Даг. Охотники считают, что гора названа из-за обилия обитающих здесь косуль и маралов, окраска шерсти которых издали кажется красной, как мне рассказал Кара-оол (Виктор) Опейович Хертек².

Кызыл-Тайга. Как считает житель поселка Кан-оол Салчакович Чульдум ${ }^{3}$, ороним Кызыл-Тайга образовался из-за обилия зарослей кызыл-хаак - 'краснотала'.

Кызыл-Тей. В ходе перекочевок этот холм служит местом отдыха у аратов. Возвышается он отдельной островной грядой, близ которой протекает родниковый ручей (информатор Лакмаа Дарымаа-ооловна Салчак ${ }^{4}$ ).

Тейлээр. Жительница Бай-Тайгинского кожууна Долзан Достаковна Кужугет ${ }^{5}$ вспоминает: «Однажды мои бабушка и дедушка переезжали из весеннего пастбища на летнее. Мы, дети, помогали перегонять отару на чайлаг. Когда же все переехали на новое место, она показала на скалу и пояснила: “Это наш Бурган. Оршээ Хайыракан! Посмотри, как он похож на человека, который молится, а на руках чётка. Как будто читает тарину и молится. ... Это святое место, все прохожие здесь обязательно останавливаются, молятся, угощают хозяина горы всем, чем богаты”».

Хемчик. Гидроним Хемчик требует детального рассмотрения.

О Хемчике сложено много песен, легенд. Народ любовно называет его «младшим братом Улуг-Хема», «маленькой колыбелью Тувы» ${ }^{6}$ Известный географ Г. Е. Грумм-Гржимайло отмечал, что «Хемчик всюду красив, но особенно поэтичны места, где его воды омывают утесы, которыми обрываются надвигающиеся на него горы» (Грумм-Гржимайло, 1914: 234).

В очерках достопримечательностей Тувы Ф. А. Журавлева и 3. И. Журавлевой пишется:

«Река Хемчик - своенравный красавец, рожденный в заоблачных высотах Козера, одного из хребтов Шапшала. В истоках река бежит по глубокой, вспаханной древним ледником долине, дно которой украшает ожерелье из двенадцати небольших аквамариновых озер. Между озерами - хаос из обломков скал, крупных валунов и древних морен. Долина падает на юго-восток пятью уступами.

\footnotetext{
${ }^{1}$ Хертек Тавак-оол Самданчапович, 1935 г. рожд. Вырос в пос. Кызыл-Тайга.

${ }^{2}$ Хертек Кара-оол (Виктор) Опейович, 1953 г. рожд. Мой отец. Охотник и рыбак. Вместе обошли изучаемые места. Научил любить и беречь свой край.

${ }^{3}$ Чульдум Кан-оол Салчакович, 1941 г. рожд. Директор музея «Оргээ» с. Кызыл-Даг.

${ }^{4}$ Салчак Лакмаа Дарымаа-ооловна, 1948 г. рожд. Учитель географии и биологии пос. Кызыл-Тайга.

${ }^{5}$ Кужугет Долзан Достаковна, 1940 г. рожд. Сестра моей бабушки, выросла в местечке Ак-Тей.

${ }^{6}$ «Большая колыбель»-Улуг-Хем.
} 
Одна из легенд рассказывает о происхождении реки. Давным-давно жила девушка по имени Хемчик. Спустя некоторое время она родила мальчиковблизнецов. В то время в их край пожаловал злой дракон “Амырга-Моос”, который пожирал всех мальчиков. Об этом узнала Хемчик, и, не зная, как спасти сыновей, она отдала их хану Бай-Тайге. Когда же Амырга-Моос приблизился к юрте хана, Бай-Тайга кинул старшего сына на северо-запад и превратил его в оз. Кара-Холь (“Чёрное озеро”), расположенное между острыми скалами; младшего бросил в ущелье и в тот же миг он стал Даштыг-Холем, “Каменистым озером”. Хемчик очень скучала по своим сыновьям и, мечтая однажды встретиться с ними, превратилась в бурную реку, чтобы с ними соединиться...» (Журавлев, Журавлева, 1981: 103).

Кемь, кем, хем - широко распространённый элемент в топонимии среднего и верхнего Енисея. Современные тувинцы это слово употребляют в значении «река». Древнейшее название Енисея кем, хем имело смысл «большая река» и в этом значении оно было употреблено не только у тувинцев, енисейских киргизов, хакасов, но и тунгусов, самодийцев, проживавших в нижнем течении р. Енисея.

Есть указания, что тунгусы Енисей называли Кем-ма в значении «большая река», некоторые ученые считают, что термин кем - угрофинский энтоним, т. е. название племени, проживавшего некогда по Верхнему Енисею, по её притоку р. Хемчик, затем передвинувшемуся вниз по Енисею - по рекам Кемчуг и Кемь. Позже известный тунгусовед Г. М. Василевич подтвердил эту версию и указал на слово йэне, которое сохранилось в крайних западных и восточных группах эвенков в значении «большая река», тогда как обычная река - бира (Василевич, 1958). Ведь название Кемчиг, кемчуг соответствует южно-самодийскому Кемчага, где чага - 'река', а Кемчага - река племени Кем.

Далее, на западе России, на территории прошлого и современного расселения финно-угорских народов, масса топонимов от основы кем, кемь: р. Кемь, пр. оз. Белого, рр. Джуты-Кем, Кара-Кем на Алтае. А. П. Дульзон в пределах территории Тувы и прилегающей части Алтая насчитал около 90 гидронимов с компонентом Кем, Хем, образующих здесь плотный ареал (Дульзон, 1964). Э. М. Мурзаев в своей работе обосновал тезис об индоевропейской принадлежности тувинского хем - «река», возведя этот элемент к древнеиндийскому Кам (кем) - «вода» (Мурзаев, 1984).

\section{Ведомость топонимики междуречья Алаш - Хонделен - Хемчик}

Собранный нами материал оформлен в виде ведомости - краткой сводки, списка географических названий исследуемой площади, которая может стать, мы считаем, основой для дальнейшего изучения топонимики края. В него включено более 36 названий, известных большинству населения. Ведомость далеко не исчерпывает богатства географической лексики народа. С сожале- 
нием следует отметить, что в некоторых случаях названия не были включены в ведомость из-за отсутствия надежной топонимической информации. Наша задача заключалась в отборе наиболее убедительных гипотез.

Ведомость сопровождается указателем принятых сокращений и объяснением топонимических терминов, встречающихся в словаре. Он позволяет получить ответ на вопросы, издревле интересующие людей: кто, какой народ присвоил название, когда это было, почему именно это название?

Список сокращений, принятый в ведомости:

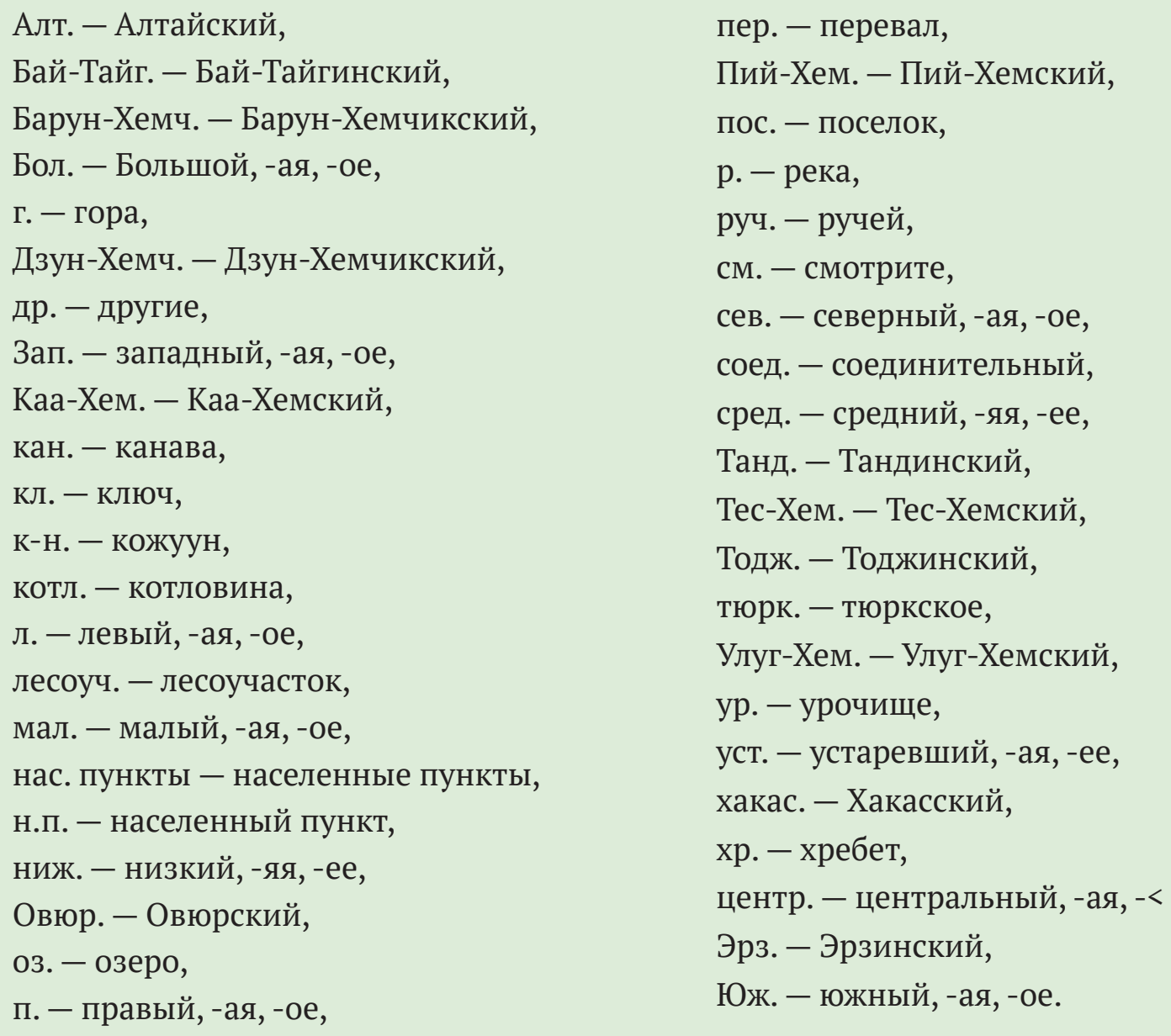

Расположение топонимов долины рек Хемчик, Алаш и Хөнделең / Хонделен показано на рисунках 6-8.

1. Ак-Довурак - г., тув. - ‘белая земля’. Месторождение асбеста, имеющего белый цвет. Возможно также обусловлено разрушившимися выходами белого магнезита, т. к. и асбест, и магнезит всегда связаны с одними и теми же породами - гипербазитами.

2. Аксы-Барлык - пос., тув. аксы - 'устье реки', Барлык - р. п. п. р. Хемчик (см. Барлык), т. е. поселок вблизи устья реки Барлык. 
3. Ажыг-Кара-Суг - родник, тув., ажыг - 'кислый, горький', кара-суг - 'источник' (см. Кара-Суг); целебный минеральный источник с кислой водой (аржаан). Находится вблизи г. Сарыг-Хая. Этот аржаан люди с давних пор почитали, совершали вблизи ритуальные обряды, очищались от злых духов, лечились священной водой.

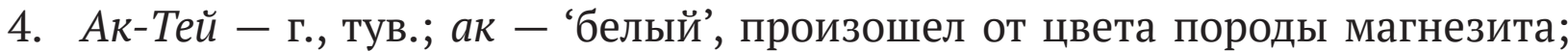
тей - 'холм, сопка'.

5. Алаш - р., л. п. р. Хемчик; предположительно, название связано с тюркским племенным этнонимом алаш, отмеченным у казахов и ногайцев (Ондар, 1995: 9).

6. Амыл - руч., возможны этимологии: др.-тюрк. амыл - 'тихий; смирный, спокойный’, также монг. эмээл - ‘седловина'. Подобный топоним имеется в Хакасии.

7. Аныяк-Теректиг - руч. п. п. р. В. Хонделен, тув.; аныяк - 'малый', терек ‘тополь', назван по тополевым лесам (Татаринцев, Шактаржик, 1972).

8. Барлык - р., п. п. р. Хемчик. Барлык берет начало с хребта Цаган-Шибэту (Монгун-Тайга), протекает в лесистой крутой долине и вскоре после слияния с р. Шуй (Бай-Тайга) выходит в Хемчикскую котловину (Барун-Хемчик), где растекается на ряд рукавов. Летние ливневые паводки Барлыка имеют огромную разрушительную силу и всегда неожиданны. О. Т. Молчанова предполагает, что алт. и тув. гидроним Барлык происходят от названия монг. племени барлуг (р. Барлуг-Гол в Монголии) (Молчанова, 1979: 150). В современном тувинском языке слово барлык отсутствует, известно в ряде тюркских языков в значении 'имущество, существующий, имеющийся, наличный’. Барлык предположительно ‘река, где все имеется в достатке' (Ондар, 1995: 12).

9. База-Хаак - канн., л. п. р. Хемчик; тув.; база - союз, соед. 'и’; в значении ‘еще, тоже, также’; т. е. 'тоже река с мелким тальником’.

10. Бай-Тайга - хр., в Бай-Тайг. к-не; тюрк. бай - ‘богатое, обильное’, тай$2 a$ - ‘высокогорье, горы с таежной растительностью’.

11. Борбак-Даг - г., тув.; борбак - круглая, овальная, даг - 'гора'.

12. Кара-Даш - г., тюрк., кара - 'черный, темный', произошел от темной красно-бурой окраски пород месторождения глин; даш - ‘камень'.

13. Кара-Суг - руч., тюрк., имеет значение родниковой реки, ключа, источника. «Карасу - родниковые воды, немноговодные реки, питающиеся выклиниванием подземных вод, обычно обладающие прозрачной водой (Мурзаев, 1984: 483). В Туве кара-суг родниковые ручьи с чистой прозрачной водой (особенно в истоках).

Көк-Сөөк / Koк-Coок - долина в Хемч. котл; тув. Из легенды следует, что в прежние времена «белые» отряды опустошали земли, разрушали монастыри 
хүрээ, и тогда небо вокруг потемнело, собрались черные тучи и грянул гром. Полил сильный ливень и своим градом погубил всех людей, разорявшие тувинскую землю, и по всей местности рассеял кости умерших. С тех пор эту долину назвали Кок-Соок: көк - 'синяя', сөөк - 'кость' (информатор Сержин Достаковна Кужугет $\left.{ }^{1}\right)$. В прилагаемом к книге «Мифы, легенды, предания тувинцев» (Мифы ... , 2010) компакт-диске на тувинском языке записана легенда аналогичного содержания, но место называется Къөп-Сөөк / Коп-Сек, къөn - ‘много’.

14. Кызыл-Даг - г., тюрк., кызыл - 'красный’ из-за наличия игнимбритов (спекшихся туф), которые зависят от соотношения окисных и закисных соединений железа, определяющим цвет породы; даг - 'гора'.

15. Кызыл-Тайга - пос., тюрк; кызыл - 'красный', топоним указывает на красноцветные породы геологического района, а также обилие зарослей краснотала кызыл-хаак.

16. Кызыл-Тей - г., тюрк, тув., кызыл - ‘красный’, по красно-бурой окраске глинистых отложений - продуктов геологического выветривания; тей - 'холм, сопка'.

17. Мажалык - г., тув., маленький каменистый холм.

18. Ногаан-Хөл / Ногаан-Холь - оз., тув., от которого берет начало р. Верх. Хонделен; ногаан - 'зеленый', хөл - 'озеро', т. е. 'озеро окруженное богатой растительностью, не подверженной летней засухе’.

19. Оваалыг-Тей - г., тув., оваа - 'насыпь, курган, жертвенный курган'. Собрана груда камней на возвышенном месте, где совершается религиозный обряд в честь духа горы. Обязательно проезжающие мимо люди должны остановиться, чтобы помолиться. Тей - 'холм, сопка'.

20. Ортаа-Хаак - кан., л. п. р. Хемчик; тув. ортаа - 'средний, расположенный в середине', в соотносительных рядах Хаак-Суг (см) и База-Хаак (см); хаак - 'тальник', т. е. 'средняя река с тальником'.

21. Сайыр - руч., лог.; тюрк., монг., тув.; 'сухое русло', нижняя часть небольшой реки, которая не доносит своих вод до устья, иссякает и оставляет свои наносы - гальку, дресву; песок в конусах выноса; «мелководье» сайыры (сайры) обладают наземной водой только во время дождей.

22. Сарыг-Хая - г., тув.; сарыг - 'желтый', т. е. произошел от преобладающей массы светлоокрашенной желтой мягкой породы -агальматолита; хая - скала.

23. Теректиг - руч., п. п. р. Хонделен: терек - 'тополь', досл. 'река с тополем'.

24. Тейлээр - г., тув.; т. е. гора, похожая на молящегося человека, произошла от неправильной формы и различной глубины залегания горного массива.

${ }^{1}$ Кужугет Сержин Достаковна, 1929 г. рожд. Моя бабушка, собирает этнографический материал по району. 
25. Тээли-шөлу / Тээли-шолу - долина в Хемч. котл., тув., Тээли - село в БайТайг. к-не, шөлу, шөл - ‘поле’, т. е. это часть долины Хемчика, которая находится около села Тээли.

26. Узун-Даг - г., тув., тюрк., узун - 'длинная, высокая', даг - 'гора'.

27. Улуг-Даг - г., тув., тюрк., улуг - ‘большая, крупная', даг - 'гора'. Она заметно выделяется среди других окружающих гор.

28. Хаак-Суг - кан., л. п. р. Хемчик; тув., тюрк., хаак - 'мелкий тальник’, суг 'река', т. е. река, изобилующая мелким тальником по берегам.

29. Хемчик - p., л. п. р. Улуг-Хем, протекает по территории Бай-Тайг., БарунХемч., Дзун-Хемч., Сут-Хол., Чаа-Хол. к-нов.

В русских исторических документах XVII в., упоминается река Кемчага (совр. Хемчик). Некоторые исследователи (А. П. Дульзон) считают гидроним Кемчик (Кемчаго) самодийским (Дульзон, 1964). В составе названия содержится уменьшительный аффикс -чик, т. е. «небольшой реки». Мотивировано сравнением с Улуг-Хемом - «Великой рекой» (Ондар, 1995: 37).

30. Хөнделең / Хонделен - р., л. п. р. Хемчик в Барун-Хемч. к-не; монг. хундэлэн «поперек». Э. М. Мурзаев пишет, что Конделен, Хунделэн встречается десятки раз и обычно употребляется для обозначения рек (или долин) второго порядка, расположенных поперечно или перпендикулярно по отношению к основной водной артерии (Мурзаев, 1984: 266). Хонделен - река, расположенная поперечно по отношению к основной реке - Хемчику (Ондар, 1995: 38).

31. Хөнделең-Тей - г., тув., Хонделен - р., л. п. р. Хемчик; тей - 'холм, сопка', т. е. горка, находящаяся рядом с р. Хонделен.

32. Чечектиг-Даг - г., тув., тюрк., чечектиг названа по обилию цветущих растений (чечек - 'цветок') высокогорных лесов (купальница, горечавка, марьин корень т. д.), даг - 'гора'.

33. Чинге-Даг - г., тув., тюрк.; чинге - 'острая, тонкая', даг - 'гора'.

34. Чаа-Барлык - кан., п. П. р. Хемчик; тув., чаа - 'новый (-ая)', Барлык - p., п. п. р. Хемчик, т.е. новая река вблизи р. Барлык.

35. Шивилиг-Даг - г., тув., тюрк., шиви - 'ель', даг - 'гора', т. е. названа по обилию ели.

\section{Заключение}

Проведенная нами работа показала, что толкование многих географических объектов рассмотренной местности связана с наблюдениями населения за их особенностями форм, цвета и пр., т. е. геологии и геоморфологии. Для систематического анализа нами составлена ведомость тувинских географических 
названий местности, показан их географо-топонимический смысл. В связи с искажением большинства названий района на географических картах и в различных печатных изданиях мы выявили исходные формы и показали неправильность истолкования топонимов.

Полагаю, что необходимо продолжение работы над изучением всех географических интерпретаций топонимов рассмотренного района, а также других районов республики.

\section{СПИСОК ЛИТЕРАТУРЫ}

Арапчор, А. Д. (1995) Тыва улустуң мифтери болгаш тоолчургу чугаалары [Мифы и предания тувинцев]. Кызыл: Тываның ном үндүрер чери. 144 а. (На тув. яз.).

Василевич, Г. М. (1958) Топонимика Восточной Сибири // Известия Всесоюзного географического общества. Т. 90, Вып. 5. С. 324-335.

Волостнова, М. Б., Тюрин, С. А. (1971) Словарь географических терминов и других слов, встречающихся в топонимии Тувинской АССР. М. : б. и. 113 с.

География терминнериниң орус-тыва словары [Русско-тувинский словарь географических терминов] (1959) / под ред. А. М. Чымба. Кызыл : Тывоблиздат. 89 с. (На рус. и тув. яз.).

Грумм-Гржимайло, Г. Е. (1914) Западная Монголия и Урянхайский край. СПб. : Издание ученого комитета Монгольской Народной Республики. Т. 2. 569 с.

Дульзон, А. П. (1964) Топонимия Западной Сибири, как один из источников ее древней истории // Из истории Кузбасса / под ред. З. Г. Карпенко. Кемерово : Книжное издательство. 268 с. С. 246-257.

Журавлев, Ф. А., Журавлева, З. И. (1981) Путешествуем по Туве: очерки о достопримечательностях Тувы. Кызыл : Тувкнигоиздат. 138 с.

Иргит, С. (1992) Тыва черниң чаражы [Красота тувинской земли] // Башкы. № 2. С. 70-71. (На тув. яз.).

Кудрявцев, В. И. (1996) Камнесамоцветное сырье Республики Тыва. Кызыл : ТувИКОПР СО РАН. 74 с.

Куулар, Д. С. (1996) Кыс-Халыыр: Тыва улустуң тоолчургу болгаш төөгү чугааларының чыыжызының катап үндүрүлгези [Тувинские народные легенды и предания] / Куулар Д. С., Куулар Ч. Ч. Кызыл : Тываның ном үндүрер чери. $157,[2]$ с. (На тув. яз.).

Мифы, легенды, предания тувинцев (2010) / отв. ред. Н. И. Коновалова. Новосибирск : Наука. 372 с. 
Молчанова О. Т. (1979) Топонимический словарь Горного Алтая. Горно-Алтайск : Алт. кн. изд-во. 116 с.

Мурзаев Э. М. (1984) Словарь географических терминов. М. : Мысль. 653 с.

Носин, В. А. (1957) Природные районы Тувинской области // Природные условия Тувинской автономной области. Труды Тувинской комплексной экспедиции. М. : Издательство АН СССР. Вып. III. С. 240-264.

Ондар, Б. К. (1992) На уроках - топонимический материал // Башкы. № 1 (18). C. 34-36.

Ондар Б. К. (1995) Краткий словарь гидронимов Тувы. Кызыл : Тувинское книжное издательство. 48 с.

Ондар, Б. К. (2007) Топонимический словарь Тувы. Кызыл : Тув. кн. изд-во. 552 с.

Потапов, Л. П. (1969) Очерки народного быта тувинцев. М. : Наука. 401 с.

Сат, Ш. Ч. (1970) Заметки по топонимике // Тувинская правда. 20 сентября. C. 4.

Татаринцев, Б. И. (1993) О некоторых древних топонимах тюркского происхождения на территории Тувы // Вопросы тувинского языкознания : сборник материалов / отв. ред. Д. А. Монгуш, Б. И. Татаринцев. Кызыл : Новости Тувы. 126 c. C. $105-113$.

Татаринцев, Б. И., Шактаржик, К. О. (1972) Словарь по топонимике Тувы // Тувинская правда, 9 мая. С. 4.

Ханмагомедов, Х. Л. (1987) Происхождение географических названий. Кызыл : Изд-во КГПИ. 18 стр.

Хертек, Л. К. (2001) Опыт географической интерпретации топонимики междуречья Алаш-Хемчик : дипломная работа (рукопись). Кызыл. 93 с.

Хертек, Р. А. (2000) Бай-Тайга кожуунуң топонимнери [Топонимы БайТайгинского кожууна] : дипломная работа (рукопись). Кызыл. 67 с. (На тув. яз.).

Дата поступления: 12.09.2017 2.

\section{REFERENCES}

Arapchor, A. D. (1995) Tyva ulustuң mifteri bolgash toolchurgu chugaalary [Myths and legends of Tuvans]. Kyzyl, Tyvanyң nom Yndyrer cheri. 144 p. (In Tuv.).

Vasilevich, G. M. (1958) Toponimika Vostochnoi Sibiri [Toponymy Of Eastern Siberia]. Izvestiia Vsesoiuznogo geograficheskogo obshestva, vol. 90, issue 5, pp. 324335. (In Russ.). 
Volostnova, M. B. and Tiurin, S. A. (1971) Slovar' geograficheskikh terminov i drugikh slov, vstrechaiushchikhsia v toponimii Tuvinskoi ASSR [A Dictionary of geographical terms and other words found in the toponymy of Tuvan ASSR]. Moscow, s. n. 113 p. (In Russ.).

Geografia terminneriniң orus-tyva slovary [A Russian-Tuvan dictionary of geographical terms] (1959) / ed. by A. M. Chymba. Kyzyl, Tyvoblizdat. 89 p. (In Russ. and Tuv.).

Grumm-Grzhimailo, G. E. (1914) Zapadnaia Mongoliia i Uriankhaiskii krai [Western Mongolia and Urankhai krai]. St. Petersburg, Publication of the scientific Committee of the Mongolian people's Republic. Vol. 2. 569 p. (In Russ.).

Dul'zon, A. P. (1964) Toponimiia Zapadnoi Sibiri, kak odin iz istochnikov ee drevnei istorii [The toponymy of Western Siberia as one of the sources of its ancient history]. In: Iz istorii Kuzbassa [From the history of Kuzbass] / ed. by Z. G. Karpenko. Kemerovo, Knizhnoe izdatel'stvo. 268 p. Pp. 246-257. (In Russ.).

Zhuravlev, F. A. and Zhuravleva, Z. I. (1981) Puteshestvuem po Tuve: ocherki o dostoprimechatel' nostiakh Tuvy [Travelling in Tuva: essays on the sights of Tuva]. Kyzyl, Tuvknigoizdat. 138 p. (In Russ.).

Irgit, S. (1992) Tyva cherniң charazhy [The beauty of Tuvan land]. Bashky, no. 2, pp. 70-71. (In Tuv.).

Kudriavtsev, V. I. (1996) Kamnesamotsvetnoe syr'e Respubliki Tyva [Raw gemstones in the Republic of Tuva]. Kyzyl, TuvIKOPR SO RAN. 74 p. (In Russ.).

Kuular,D.S.(1996) Kys-Khalyyr: Tyva ulustuß toolchurgu bolgash tөөgychugaalarynyң chyyzhyzynyн katap yndyrylgezi [Maiden rock: Tuvan folk legends and legends] / Kuular D. S. and Kuular Ch. Ch. Kyzyl, Tuvinskoe knizhnoe izdatel'stvo. 157, [2] p. (In Tuv.).

Mify, legendy, predaniia tuvintsev [Myths, legends and tales of Tuvans] (2010) / ed. by N. I. Konovalov. Novosibirsk, Nauka. 372 p. (In Russ.).

Molchanova O. T. (1979) Toponimicheskii slovar' Gornogo Altaia [A Toponymical dictionary of Gorny Altai]. Gorno-Altaisk, Alt. kn. izd-vo. 116 p. (In Russ.).

Murzaev E. M. (1984) Slovar' geograficheskikh terminov [A Dictionary of geographical terms]. Moscow, Mysl'. 653 p. (In Russ.).

Nosin, V.A.(1957) Prirodnye raiony Tuvinskoi oblasti [Natural areas of Tuva region]. In: Prirodnye usloviia Tuvinskoi avtonomnoi oblasti. Trudy Tuvinskoi kompleksnoi ekspeditsii [Natural conditions of the Tuva Autonomous region. Works of Tuva complex expedition]. Moscow, AN SSSR Publ. Vol. III. Pp. 240-264. (In Russ.).

Ondar, B. K. (1992) Na urokakh - toponimicheskii material [Using toponymical material in the classroom]. Bashky, no. 1 (18), pp. 34-36. (In Russ.).

Ondar B. K. (1995) Kratkii slovar' gidronimov Tuvy [A Concise dictionary of hydronyms of Tyva]. Kyzyl, Tuvinskoe knizhnoe izdatel'stvo. 48 p. (In Russ.). 
Ondar, B. K. (2007) Toponimicheskii slovar' Tuvy [A Toponymical dictionary of Tuva]. 2nd ed. Kyzyl, Tuvinskoe knizhnoe izdatel'stvo. 552 p. (In Russ.).

Potapov, L. P. (1969) Ocherki narodnogo byta tuvintsev [Essays on the traditional life of Tuvans]. Moscow, Nauka. 402 p. (In Russ.).

Sat, Sh. Ch. (1970) Zametki po toponimike [Notes on toponymics]. Tuvinskaia pravda, 20 September, p. 4. (In Russ.)

Tatarintsev, B. I. (1993) O nekotorykh drevnikh toponimakh tiurkskogo proiskhozhdeniia na territorii Tuvy [On some old place names of Turkic origin in the territory of Tuva]. In: Voprosy tuvinskogo iazykoznaniia [Questions of Tuvan linguistics]: a collection of materials / ed. by D. A. Mongush and B. I. Tatarintsev. Kyzyl, Novosti Tuvy. 126 p. Pp. 105-113. (In Russ.).

Tatarintsev, B. I. and Shaktarzhik, K. O. (1972) Slovar' po toponimike Tuvy [A Dictionary of Tuvan toponymy]. Tuvinskaia pravda, 9 May, p. 4. (In Russ.).

Khanmagomedov, Kh. L. (1987) Proiskhozhdenie geograficheskikh nazvanii [The genesis of place names]. Kyzyl, KGPI Publ. 18 p. (In Russ.).

Khertek, L. K. (2001) Opyt geograficheskoi interpretatsii toponimiki mezhdurech'ia Alash-Khemchik [An attempt at geographical interpretation of place names in the AlashKhemchik interfluve]: a thesis (manuscript). Kyzyl. 93 p. (In Russ.).

Khertek, R. A. (2000) Bai-Taiga kozhuunuң toponimneri [The names of Bai-taiga kozhuun] : graduation work (manuscript). Kyzyl. 67 p. (In Tuv.).

Submission date: 12.09 .2017$.

\section{Для циитирования:}

Хертек Л. К. Ведомость топонимики междуречья Алаш-Хемчик [Электронный ресурс] // Новые исследования Тувы. 2018, № 3. URL: https://nit.tuva.asia/nit/article/ view/734 (дата обращения: дд.мм.гг.). DOI: 10.25178/nit.2018.3.15

\section{For citation:}

Khertek L. K. Place names of the Alash-Khemchik interfluve: a list. The New Research of Tuva, 2018, no. 3 [on-line] Available at: https://nit.tuva.asia/nit/article/view/734 (accessed: ... ). DOI: 10.25178/nit.2018.3.15 